\title{
PENGARUH CARA PERENDAMAN DAN JENIS KENTANG TERHADAP MUTU KERIPIK KENTANG
}

\author{
THE EFFECT OF SUBMERSION AND POTATO TYPE ON THE QUALITY OF \\ POTATO CHIPS
}

\author{
Judith Henny Mandei ${ }^{1)}$, Alim Mahawan Nuryadi ${ }^{2)}$ \\ ${ }^{1,2)}$ Balai Riset dan Standardisasi Industri Manado, 95112 \\ *Hp 08124443392, e-mail: nenimandei@yahoo.com
}

\begin{abstract}
ABSTRAK
Penelitian pengaruh cara peredaman dan jenis kentang terhadap mutu keripik kentang telah dilaksanakan. Penelitian bertujuan untuk melihat pengaruh cara perendaman dan varitas kentang terhadap mutu dari keripik kentang. Penelitian ini menggunakan metode deskriptif trial and error, dengan dua jenis kentang (kentang lokal dan kentang mentega), dengan beberapa cara perendaman yaitu: $A=$ Perendaman dalam air dingin dilakukan berulang kali sampai air yang digunakan untuk merendam kentang berwarna jernih; $\mathrm{B}=$ Perendaman dalam air panas pada suhu $80{ }^{\circ} \mathrm{C}$ selama 5 menit dan disiram dengan air panas $\left(100{ }^{\circ} \mathrm{C}\right) ; \mathrm{C}=$ Perendaman dalam larutan kapur $1,5 \%$, selama 30 menit; $\mathrm{D}=$ Perendaman dalam larutan soda kue 1\% selama 30 menit; $E=$ Rendam air dingin berulang kali dilanjutkan dengan siram air mendidih $100^{\circ} \mathrm{C}$ (kentang lokal); dan $\mathrm{F}=$ Rendam air mendidih $100^{\circ} \mathrm{C} 1$ menit dilanjutkan rendam air dingin (kentang mentega). Pengamatan dilakukan terhadap bahan baku kentang (kadar pati, kadar air, kadar gula, dan kadar abu), serta produk keripik kentang [kadar air, kadar abu, kadar lemak, serta uji sensoris (warna, bau, rasa dan tekstur/kerenyahan)]. Uji kerenyahan keripik kentang berdasarkan intensitas suara $(\mathrm{dB})$ dilakukan pada penyimpanan 0 dan 7 hari. Mutu keripik kentang dipengaruhi oleh jenis kentang dan cara perendaman. Berdasarkan nilai organoleptik dan pengujian kerenyahan, jenis kentang yang lebih sesuai dijadikan keripik adalah jenis kentang mentega, dimana sampai penyimpanan hari ke-7 masih menghasilkan tekstur yang renyah. Sedangkan untuk jenis kentang lokal yang memenuhi syarat mutu keadaan keripik berdasarkan SNI 01-4031-1996 adalah keripik kentang yang dihasilkan dengan perendaman pada larutan soda kue 1\% selama 30 menit (perlakuan D). Berdasarkan mutu kimia keripik kentang yang, memenuhi syarat mutu adalah keripik kentang yang dibuat dengan cara perendaman pada suhu $80^{\circ} \mathrm{C}$ selama 5 menit dilanjutkan dengan disiram dengan air mendidih $100{ }^{\circ} \mathrm{C}$ (perlakuan B) dengan hasil kadar air 2,81\%, kadar abu 1,75\% dan kadar lemak 42,28\%.
\end{abstract}

Kata Kunci: Kentang, keripik, mutu, perendaman

\begin{abstract}
Research on the effect of submersion and potato chips has been implemented. This research aims to see the effect of submersion and potato varietieson the quality of potato chips. This research uses descriptive trial and error method, with two types of potato (local potato and butter potato), by some method of submersion that that is: $A=S$ Submersion in cold done repetatedly until the water used to soak the clear colores potatoes; $B=S u b m e r s i o n$ in hot water at $80^{\circ} \mathrm{C}$ for 5 minutes and doused with hot water $\left(100^{\circ} \mathrm{C}\right)$; $C=$ Submersion in $1,5 \%$ lime solution, for 30 minutes; $D=$ Submersion in $1 \%$ baking soda solution for 30 minutes. Observations were made on potate feedstock (starch content, water content, sugar content and ash content), and potato chipsproduct [water content, ash content, fat content, and sensory tests (color, odor, taste and texture/crispness)]. Test of crispy potato chips based on sound intensity (dB) is done on storage 0 and 7 days. The quality of potate chips is influenced by the type of potato and the way of submersion. Based on organoleptic value and crispness testing, a more suitable type of potate chips is a typeof butter potato, which until $7^{\text {th }}$ day of storage still yields a crisp texture. While for the local potato type that qualifies the state of chips based on SNI 01-4031-1996 is potate chips produced by submersion in $1 \%$ baking soda solution for 30 minutes (treatment D). Based on the chemical quality of potato chips, qualified as potato chips made by immersionat $80^{\circ} \mathrm{C}$ for 5 minute followed by flushing with boiling water $100^{\circ} \mathrm{C}$ (treatment B) with water content of $2,81 \%$, ash content of 1,75 and fat content $42,28 \%$.
\end{abstract}

Keywords: Potato, chips, quality, soaking

\section{PENDAHULUAN}

Di provinsi Sulawesi Utara, tanaman kentang merupakan komoditas unggulan yang telah memberi kontribusi pasokan terhadap produksi kentang nasional.

Kentang berpeluang untuk dikembangkan

secara berkelanjutan dalam rangka

peningkatan pendapatan dan 
kesejahteraan petani. Pengembangan kentang di provinsi Sulawesi Utara direalisasikan dengan ditentukannya kawasan pengembangan kentang "Modassi" (Modoinding, Modayag dan Passi). Potensi lahan yang tersedia di dataran tinggi provinsi Sulawesi Utara seluas 875.000 ha, sedangkan yang tersedia di kawasan "Modassi" adalah 22.860 ha dan yang telah dimanfaatkan sekitar 16.000 ha [1].

Kentang dapat diolah menjadi berbagai macam produk makanan diantaranya adalah keripik kentang. Pengolahan kentang menjadi keripik merupakan tahapan pasca panen yang ditempuh untuk pengembangan diversifikasi produk dan peningkatan nilai tambah. Di Indonesia, dua jenis produk olahan kentang yang menunjukkan kecenderungan semakin populer dalam pola konsumsi masyarakat adalah kentang goreng (french fries) dan keripik kentang (potato chips) [2].

Ada beberapa faktor yang mempengaruhi mutu dari keripik kentang diantaranya cara perendaman dan varitas atau jenis kentang. Perendaman dengan air panas menginaktifkan dan merusak enzim sehingga reaksi pencoklatan dapat dicegah dan warna keripik menjadi cerah. Keripik kentang yang baik berasal dari umbi kentang yang mempunyai kadar air dan gula rendah serta kadar pati tinggi . Kadar air yang terlalu tinggi akan menghasilkan keripik kentang dengan tekstur kurang renyah. Kadar gula yang tinggi pada kentang akan menurunkan kualitas keripik kentang terutama warnanya karena akan mempercepat terjadinya reaksi pencoklatan
Maillard antara gula pereduksi dengan gugus amina primer menghasilkan senyawa melanoidin yang menghasilkan produk berwarna coklat dan tidak dikehendaki dalam pembuatan keripik kentang. Kadar pati yang rendah akan menghasilkan keripik kentang dengan tekstur kurang renyah [3].

Komposisi kentang atau karakteristik fisik dan kimia dari kentang dipengaruhi oleh varitasnya. Karakteristik ini mempengaruhi mutu olah dari kentang. Perbedaan sifat fisik dan kimia ini mengakibatkan tidak semua varietas kentang tepat untuk dipergunakan sebagai bahan baku keripik kentang. Mutu keripik kentang dilihat dari kenampakan (appearance), tekstur (kerenyahan) dan warna serta kandungan gizinya [4].

Atlantik merupakan varietas kentang yang umum digunakan dalam pembuatan keripik kentang. Kentang varietas Atlantik ini berwarna putih berbentuk bulat dengan diameter 6-7 cm dan panjang 10-11 cm sehingga sangat menarik apabila kentang Atlantik digunakan sebagai salah satu bahan olahan yang berupa keripik kentang. Varietas Atlantik mempunyai kadar air dan gula rendah serta kadar pati tinggi sehingga bila digunakan untuk membuat keripik dapat menghasilkan keripik yang baik. Varietas ini memiliki beberapa kelemahan antara lain: produksinya rendah, tidak tahan layu, tidak tahan busuk daun dan tidak tahan nematoda akar [5]. Keterbatasan inilah yang menyebabkan kurang berkembangnya industri makanan olahan kentang di Indonesia. Varietas kentang Granola, bila digunakan untuk industri keripik kentang menghasilkan keripik 
dengan warna yang kurang menarik (kuning kecoklatan sampai coklat) dan memiliki tekstur yang tidak renyah. Kentang varietas Granola saat ini mendominasi produksi kentang di Indonesia, yaitu mencapai $90 \%$ dari seluruh areal tanam, sedangkan kentang olahan hanya menempati $10 \%$ saja [6]. Kentang granola merupakan kentang dengan kandungan pati rendah (16 - 18\%) dan kandungan air tinggi (lebih dari $80 \%$ ). Kentang jenis ini lebih cocok diolah menjadi kentang rebus karena pori-porinya sulit mengeluarkan air pada saat pemasakan. Kentang-kentang inipun sangat disukai karena pulen dan sedikit manis rasanya. Bentuk umbi oval, warna kulit umbi kuning sampai putih, dan warna daging umbi kuning dengan permukaan kulit umbi halus. Kebanyakan kentang ini merupakan produk dalam negeri dan cocok digunakan untuk makanan tradisional.

Salah satu cara yang coba digunakan untuk mendapatkan keripik kentang dengan tekstur yang renyah walaupun menggunakan jenis kentang dengan kadar pati rendah dan kadar air tinggi, adalah dengan melakukan perendaman dalam kalsium (Ca). Perendaman merupakan tahap pengolahan pangan yang memegang peranan penting terhadap kualitas pangan yang dihasilkan. Perlakuan perendaman dimaksudkan untuk mempertahankan tekstur. Perubahan tekstur menjadi lunak pada bahan pangan selama penyimpanan dan proses pengolahan menggunakan panas dapat terjadi karena adanya perubahan sifat permeabilitas sel, perubahan pektin dan pengaruh gula [8]. Perubahan kekerasan menjadi lunak ini dapat dicegah dengan perendaman dalam larutan garam-garam kalsium, karena kalsium bereaksi dengan gugus karboksil dari pektin.

Perendaman dalam larutan kapur sirih menyebabkan tekstur menjadi keras, mengurangi rasa sepat, getir dan cita rasa yang menyimpang [10]. Kalsium dapat mempertinggi kekerasan gel karena adanya ikatan kalsium dengan gugus karboksil melalui jembatan kalsium. Umbi kentang keseluruhan mengandung metoksil sebesar $1,55 \%$ dalam setiap 100 gram umbi kentang. Pektin dengan metoksil rendah lebih rendah dari $7 \%$ dapat membentuk gel bila ada ion-ion logam bervalensi dua. Kalsium yang bervalensi dua akan berikatan secara menyilang diantara dua gugus karboksil pada pektin. Bila ikatanikatan ini terdapat dalam jumlah besar, maka akan terbentuk jaringan-jaringan kalsium pektat. Larutan garam kalsium dalam bahan akan membentuk kalsium pektat yang tidak larut dalam air [8].

Keuntungan penggunaan larutan kapur $\left[\mathrm{Ca}(\mathrm{OH})_{2}\right]$ dalam perendaman bahan pangan adalah kapur yang termasuk elektrolit kuat, akan mudah larut dalam air dan ion Ca akan mudah terabsorbsi dalam jaringan bahan. Selain itu, $\mathrm{Ca}(\mathrm{OH})_{2}$ Juga dapat mencegah proses pencoklatan non enzimatis yang disebabkan oleh ion $\mathrm{Ca}$ terhadap asam amino. Reaksi pencoklatan non enzimatis umumnya terjadi bila kita memasukkan atau mengeringkan bahan makanan. Warna coklat akan timbul akibat terjadinya reaksi antara gula dengan protein atau asam amino [11]. $\mathrm{Ca}(\mathrm{OH})_{2}$ merupakan elektrolit kuat yang mudah larut dalam air. Ion $\mathrm{Ca}^{2+}$ akan mudah terabsorbsi 
ke dalam jaringan sehingga dapat memperkuat dinding sel. $\mathrm{Ca}(\mathrm{OH})_{2}$ termasuk bahan pengeras (firming-agent), untuk buah dan sayur. Ion $\mathrm{Ca}^{2+}$ akan membentuk Ca-pektat dan pektin. Garam kalsium yang bisa digunakan selain $\mathrm{Ca}(\mathrm{OH})_{2}$ adalah Ca-laktat, Ca-sitrat dan Ca-klorida. Ion kalsium juga dapat memperkuat tekstur dan mencegah browning enzimatis karena ion kalsium bereaksi dengan asam amino sehingga menghambat reaksi pencoklatan [11].

Pada pembuatan keripik, pembentukan kalsium pektat akan membantu meningkatkan porositas, sehingga meningkatkan kerenyahannya. Namun demikian, penggunaan konsentrasi $\mathrm{Ca}$ yang tinggi mengakibatkan jumlah interaksi kalsium pektat yang tinggi, sehingga tekstur produk menjadi keras. Pada $\mathrm{pH}$ larutan yang tinggi, $\mathrm{Ca}(\mathrm{OH})_{2}$ akan terionisasi menjadi $\mathrm{Ca}^{2+}$ dan $\mathrm{OH}^{-}$ membentuk ikatan silang dengan pati. Interaksi $\mathrm{Ca}^{2+}$ akan menstabilkan dinding granula pati sehingga granula pati lebih keras dan kuat [12].

Adapun tujuan dari penelitian ini adalah untuk melihat pengaruh cara perendaman dan varitas (jenis) kentang terhadap mutu keripik kentang.

\section{BAHAN DAN METODE}

\section{Bahan Penelitian}

Bahan-bahan yang digunakan dalam penelitian ini adalah umbi kentang lokal yang diperoleh dari supermarket (kentang granola) dan umbi kentang mentega bersertifikat bebas pestisida yang diperoleh dari hypermart, minyak goreng sawit, kapur sirih, soda kue, akuades, dan kemasan plastik tara pangan.

Peralatan yang digunakan adalah loyang plastik, panci stainless steel, pisau stainless steel, peniris minyak, wajan, kompor, slicer, baki stainless steel, timbangan digital dan peralatan untuk analisis laboratorium.

\section{Metode Penelitian}

Penelitian ini menggunakan metode deskriptif trial and error. Bahan baku kentang (kentang lokal dan kentang mentega) dilakukan pengujian untuk mengetahui pengaruhnya terhadap keripik kentang yang dihasilkan. Kedua jenis kentang diperlakukan dengan beberapa cara perendaman yaitu:

$\mathrm{A}=$ Perendaman dalam air dingin dilakukan berulang kali sampai air yang digunakan untuk merendam kentang berwarna jernih.

$\mathrm{B}=$ Perendaman dalam air panas pada suhu $80{ }^{\circ} \mathrm{C}$ selama 5 menit dan disiram dengan air panas $\left(100^{\circ} \mathrm{C}\right)$.

$\mathrm{C}=$ Perendaman dalam larutan kapur $1,5 \%$, selama 30 menit.

$\mathrm{D}=$ Perendaman dalam larutan soda kue $1 \%$ selama 30 menit.

\section{Prosedur kerja}

Dipilih umbi kentang yang baik (tidak busuk atau cacat) sesuai jenis yang akan digunakan, dicuci bersih dari kotoran yang melekat, kemudian dikupas. Umbi kentang yang telah dikupas, ditimbang dan dipotong-potong menggunakan slicer. Potongan kentang langsung direndam sesuai perlakuan yang dicoba. Sesudah itu potongan kentang diangkat dan ditiriskan. Untuk perlakuan C dan D dibilas satu kali, tiriskan, kemudian digoreng secara deep 
frying pada suhu $\pm 175{ }^{\circ} \mathrm{C}$ selama \pm 15 menit tergantung jumlah yang akan digoreng. Hasil gorengan ditiriskan, didinginkan dan dikemas. Keripik kentang siap dianalisis mutu kimia maupun sensoris.

\section{Pengamatan}

Pengamatan dilakukan terhadap bahan baku kentang (kadar pati metode Luff Schrool, kadar air metode gravimetri sesuai SNI 01-2891-1992 Cara uji makanan dan minuman, kadar gula metode Luff Schrool, dan kadar abu metode gravimetri sesuai SNI 01-2891-1992 Cara uji makanan dan minuman), serta produk keripik kentang (kadar air, dan kadar abu metode gravimetri sesuai SNI 01-2891-1992 Cara uji makanan dan minuman, kadar lemak metode ekstraksi soxhlet sesuai SNI 012891-1992 Cara uji makanan dan minuman), serta uji sensoris (warna, bau, rasa dan tekstur/kerenyahan sesuai SNI 01-4031-1996 Keripik kentang. Dilakukan juga pengujian tekstur menggunakan sofware khusus berdasarkan intensitas suara $(\mathrm{dB})$ pada penyimpanan 0 dan 7 hari.

Data yang diperoleh ditampilkan dalam bentuk Tabel, histogram dan grafik.

\section{HASIL DAN PEMBAHASAN}

\section{Bahan Baku Kentang}

Bahan baku kentang yang digunakan terdiri dari dua jenis yaitu kentang lokal (granola) dan kentang mentega, yang penampakannya dapat dilihat pada Gambar di bawah ini.

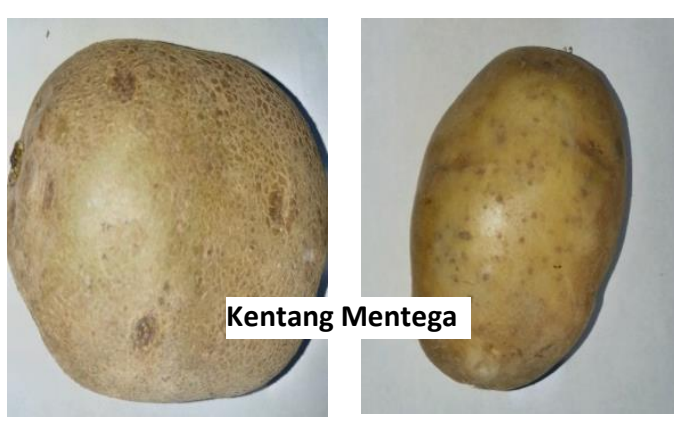

Gambar 1. Penampakan Luar Kentang Mentega dan Kentang Lokal

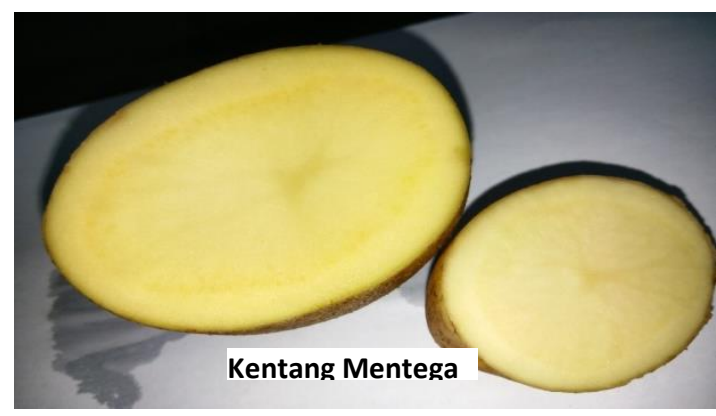

Gambar 2. Penampakan Irisan Melintang Kentang Mentega dan Kentang Lokal.

Hasil pengujian kadar air, abu, pati dan gula reduksi kentang lokal dan kentang mentega dapat dilihat pada Tabel 1 berikut ini.

Tabel 1. Hasil Pengujian Bahan Baku Kentang

\begin{tabular}{lll}
\hline \multirow{2}{*}{ Parameter Uji } & \multicolumn{2}{c}{ Jenis Kentang } \\
\cline { 2 - 3 } & Lokal & Mentega \\
\hline Kadar Air (\%) & 83,22 & 82,93 \\
Kadar Abu (\%) & 0,88 & 0,73 \\
Kadar Pati (\%) & 13,56 & 11,89 \\
Gula Reduksi (\%) & 0,66 & 0,43 \\
Bahan Kering (\%) & 16,78 & 17,07 \\
\hline
\end{tabular}

Kentang yang cocok untuk industri keripik harus mempunyai kandungan gula $<0,05 \%$, bobot kering $>20 \%$, kandungan bahan padatnya tinggi ( $\geq 16,7 \%)$, bentuk umbi baik, dan permukaan rata [13]. Sedangkan dalam Kurniawan dan [14] 
dinyatakan bahwa 2,5-3 $\mathrm{mg} / \mathrm{gr}$ dipandang sebagai batas gula reduksi yang dijadikan standar kriteria untuk keripik kentang, dan kadar bahan kering minimum untuk standar industri pengolahan keripik yaitu 16,7\%, akan memberikan tekstur renyah pada keripik. Kentang yang memenuhi syarat pembuatan keripik kentang adalah kentang yang mengandung 20-22 \% total padatan dan 14-16 \% pati [15]. Selanjutnya dinyatakan bahwa kentang yang mengandung sekitar $13 \%$ pati apabila diolah menjadi keripik kentang akan menghasilkan keripik dengan tekstur yang lembek dan berwarna coklat.

Dari Tabel 1 dapat dilihat bahwa sesuai dengan kriteria yang ditetapkan sebagai standar bahan baku kentang untuk keripik, maka untuk kadar pati kedua jenis kentang ini tidak memenuhi syarat mutu kriteria bahan baku untuk keripik kentang. Sedangkan untuk kandungan bahan kering, kedua jenis kentang ini memenuhi syarat sebagai bahan baku kentang olahan. Untuk kandungan gula reduksi, kedua jenis kentang tidak memenuhi standar atau melewati kadar maksimum gula reduksi yang dipersyaratkan. Kandungan gula reduksi merupakan salah satu faktor yang sangat menentukan atau mempengaruhi warna dari keripik kentang [14]. Kadar gula yang tinggi pada kentang akan menurunkan kualitas keripik kentang terutama warnanya karena akan mempercepat terjadinya reaksi pencoklatan Maillard antara gula pereduksi dengan gugus amina primer menghasilkan senyawa melanoidin yang menghasilkan produk berwarna coklat dan tidak dikehendaki dalam pembuatan keripik kentang [17]. Oleh karena itu perlu adanya perlakuan awal yang sesuai sehingga dapat diperoleh keripik kentang yang memenuhi syarat mutu.

\section{A. Keripik Kentang}

1. Kadar Air

Hasil pengujian kadar air keripik kentang dapat dilihat pada Gambar 3 di bawah ini.

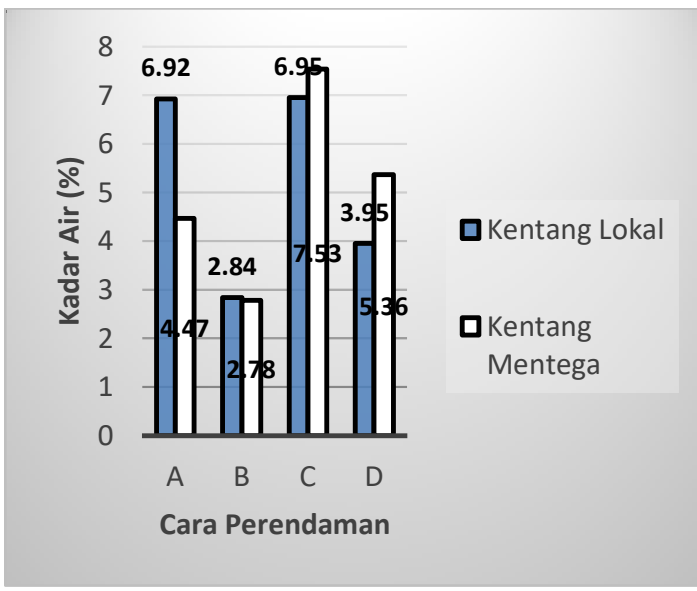

Gambar 3. Pengaruh Cara Perendaman dan Jenis Kentang terhadap Kadar Air Keripik Kentang.

Kadar air merupakan salah satu faktor penentu mutu keripik kentang. Kadar air keripik kentang yang dihasilkan dalam penelitian ini berkisar antara 0,98-7,53\% (Gambar 3). SNI 01-4031-1996 tentang syarat mutu keripik kentang mensyaratkan kadar air keripik kentang adalah maksimum $3 \%$. Berdasarkan hal ini maka kadar air keripik kentang yang memenuhi syarat mutu adalah yaitu keripik yang dibuat dengan cara merendam irisan kentang dalam air bersuhu $80^{\circ} \mathrm{C}$ selama 5 menit dilanjutkan dengan menyiram irisan kentang tersebut dengan air mendidih (perlakuan B), untuk kedua jenis kentang (lokal dan mentega). Selain itu keripik kentang yang kadar airnya memenuhi syarat adalah keripik kentang mentega yang dibuat dengan cara merendam irisan 
kentang pada air mendidih seketika, dilanjutkan dengan perendaman pada air dingin sampai air rendaman jernih.

Dari gambar 3 dapat dilihat bahwa kadar air keripik dari jenis kentang mentega cenderung lebih rendah dari keripik dari jenis kentang lokal. Hal ini dapat dilihat dari rerata kadar air keripik kentang mentega yaitu sebesar $4,22 \%$, sedangkan rerata kadar air keripik kentang lokal yaitu sebesar $5,28 \%$. Hal ini sejalan dengan yang dinyatakan dalam penelitian sebelumnya bahwa varitas kentang mempengaruhi kadar air keripik kentang, dimana tiap-tiap varitas secara genetik mempunyai kandungan air yang berbeda-beda dan mempunyai kemampuan menahan air yang berbeda-beda [16]. Perbedaan ini menyebabkan setiap produk bahan pangan memiliki kandungan air yang berbeda pula. Kadar air bahan baku kentang mentega adalah $82,93 \%$, dan kadar air kentang lokal adalah 83,22\% (Tabel 1).

Cara perendaman yang berbeda memberikan hasil keripik kentang dengan kadar air yang berbeda. Perlakuan B (keripik yang dibuat dengan cara merendam irisan kentang dalam air bersuhu $80^{\circ} \mathrm{C} 5$ selama 5 menit dilanjutkan dengan menyiram irisan kentang tersebut dengan air mendidih) memiliki kadar air yang paling rendah. Hal ini disebabkan perendaman dengan air panas akan membuka pori-pori bahan sehingga ketika bahan digoreng air yang ada dalam bahan akan mudah menguap keluar dari bahan digantikan oleh minyak. Sedangkan cara perendaman menggunakan larutan kapur sirih (perlakuan C) menyebabkan terjadinya pengerasan pada bagian luar jaringan buah sehingga keberadaan air dalam jaringan agak terhambat untuk menguap keluar jaringan ketika digoreng dan produk keripik kentang memiliki kadar air yang tinggi. Bila ion $\mathrm{Ca}^{2+}$ membentuk garam dengan karbonil dari asam galakturonat maka akan terjadi ikatan menyilang di antara gugus karbonil tersebut. Apabila jumlah ikatan menyilang yang terbentuk banyak, maka gugus pektin yang terbentuk menjadi sukar larut dan tekstur menjadi lebih keras. Ikatan yang kuat tersebut pada saat penggorengan akan mengakibatkan difusi air terhambat sehingga memungkinkan terjadinya case hardening [18].

\section{Kadar Abu}

Hasil pengujian kadar abu dari keripik kentang dapat dilihat pada Gambar 4 berikut ini.

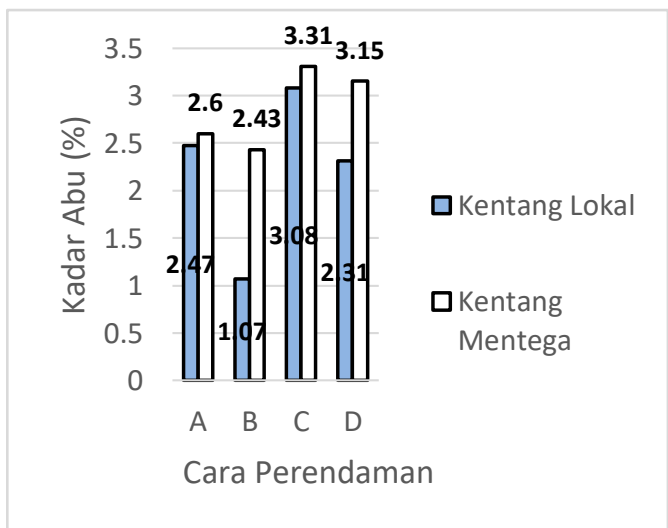

\section{Gambar 4. Pengaruh Cara Perendaman dan Jenis Kentang terhadap Kadar Abu Keripik Kentang.}

Penentuan kadar abu bertujuan untuk mengetahui banyaknya kandungan mineral yang terdapat dalam keripik kentang yang dihasilkan. Kadar abu keripik kentang yang dihasilkan dalam penelitian ini berkisar antara 0,34-3,31\% (Gambar 4). SNI 014031-1996 tentang syarat mutu keripik 
kentang mensyaratkan kadar abu keripik kentang adalah maksimum $3 \%$. Berdasarkan persyaratan ini maka keripik kentang yang dihasilkan dengan perlakuan C (perendaman dalam larutan kapur 1,5\%) untuk kedua jenis kentang, dan perlakuan D (perendaman dalam larutan soda kue) untuk jenis kentang mentega tidak memenuhi syarat mutu karena kadar abunya $>3 \%$. Hal ini disebabkan baik ion kalsium maupun natrium yang ada pada kedua larutan ini akan berpenetrasi masuk ke dalam jaringan kentang meningkatkan kandungan mineral yang ada dalam produk keripik kentang. Perendaman dalam air panas menyebabkan pori-pori bahan/jaringan kentang terbuka sehingga banyak mineral yang larut ke dalam air panas sehingga kadar abu produk keripik menjadi rendah.

\section{Kadar Lemak}

Hasil pengujian kadar lemak dari keripik kentang dapat dilihat pada Gambar 5 berikut ini.

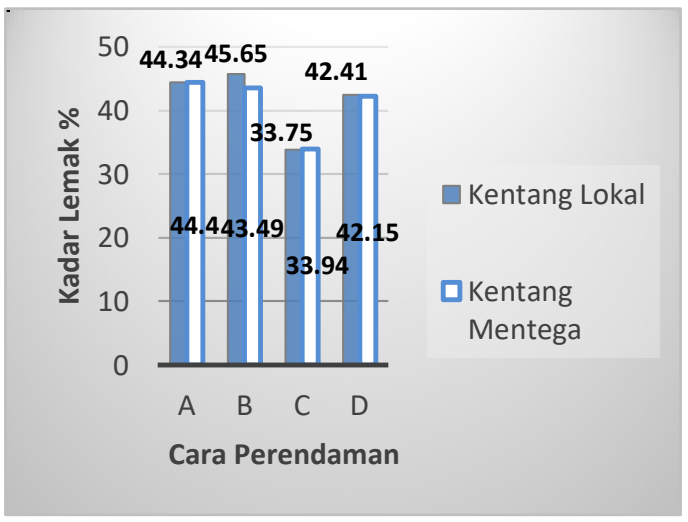

Gambar 5. Pengaruh Cara Perendaman dan Jenis Kentang terhadap Kadar Lemak Keripik Kentang.

Faktor-faktor yang mempengaruhi jumlah minyak yang terserap oleh produk yaitu kadar air bahan, ketebalan irisan, dan perlakuan pra-penggorengan. Rongga pada bahan pangan goreng akibat penguapan air bergantung pada ketebalan crust dan core [14]. Minyak yang terserap dapat berdampak positif terhadap flavor yang khas, kerenyahan produk, dan mengempukkan produk, tetapi juga dapat berdampak negatif terhadap berkurangnya tingkat penerimaan konsumen karena penampilan produk yang berminyak. Selain itu, absorpsi minyak yang tinggi dapat menyebabkan produk lebih mudah tengik. Lemak yang diabsorpsi keripik kentang sekitar 40\% [8]. Kadar lemak keripik kentang dalam penelitian ini berkisar antara 33,75-51,93\% (Gambar 5). Keripik kentang yang dihasilkan dengan perlakuan $\mathrm{C}$ (perendaman dalam larutan kapur sirih) mempunyai kadar lemak paling rendah yaitu rata-rata $33,84 \%$. Hal ini disebabkan terbentuknya ikatan antara kalsium dengan pektin dalam jaringan kentang, sehingga kentang mempunyai struktur jaringan yang kuat akibatnya tekstur yang terbentuk keras. Tekstur yang keras dapat menghambat proses penguapan air saat penggorengan sehingga air yang menguap sedikit dan mempercepat pembentukan crust, akibatnya jumlah minyak yang terserap oleh bahan juga semakin menurun. Selama proses penggorengan minyak masuk ke bagian kerak dan mengisi ruang yang pada mulanya diisi air [8].

\section{Uji Organoleptik}

Pengujian organoleptik dilakukan terhadap keadaan dari keripik kentang meliputi bau, rasa, warna dan tekstur (kerenyahan) sesuai SNI 01-4031-1996 Keripik Kentang. 
Hasil uji organoleptik (Tabel 2) menunjukkan bahwa untuk bau hampir semua produk keripik kentang menunjukkan bau normal (khas keripik kentang) kecuali bau keripik yang dihasilkan dengan perlakuan perendaman air mendidih. Bau dalam keripik kentang mengacu pada bau khas keripik kentang yang dihasilkan.

Tabel 2. Hasil Uji Organoleptik Keripik Kentang

\begin{tabular}{|c|c|c|c|c|c|c|c|c|}
\hline \multirow{3}{*}{$\begin{array}{c}\text { Cara } \\
\text { Rendam }\end{array}$} & \multicolumn{8}{|c|}{ Jenis Kentang } \\
\hline & \multicolumn{4}{|c|}{ Lokal } & \multicolumn{4}{|c|}{ Mentega } \\
\hline & $\mathrm{Bau}$ & Rasa & Warna & Tekstur & Bau & Rasa & Warna & Tekstur \\
\hline$A$ & Normal & $\begin{array}{c}\text { Kurang } \\
\text { gurih }\end{array}$ & $\begin{array}{c}\text { Kuning } \\
\text { kecoklatan/ } \\
\text { tidak merata }\end{array}$ & $\begin{array}{l}\text { Tidak } \\
\text { renyah }\end{array}$ & Normal & $\begin{array}{l}\text { Agak } \\
\text { gurih }\end{array}$ & $\begin{array}{c}\text { Kuning } \\
\text { kecoklatan/ } \\
\text { tidak merata }\end{array}$ & Renyah \\
\hline B & $\begin{array}{l}\text { Agak } \\
\text { normal }\end{array}$ & $\begin{array}{l}\text { Tidak } \\
\text { gurih/ } \\
\text { tawar }\end{array}$ & $\begin{array}{c}\text { Kuning } \\
\text { kecoklatan/ } \\
\text { kurang merata }\end{array}$ & Renyah & $\begin{array}{l}\text { Agak } \\
\text { normal }\end{array}$ & $\begin{array}{l}\text { Tidak } \\
\text { gurih/ } \\
\text { tawar }\end{array}$ & $\begin{array}{c}\text { Kuning } \\
\text { kecoklatan/ } \\
\text { tidak merata }\end{array}$ & Renyah \\
\hline C & Normal & $\begin{array}{c}\text { Kurang } \\
\text { gurih }\end{array}$ & $\begin{array}{c}\text { Kuning } \\
\text { kecoklatan/ } \\
\text { kurang merata } \\
\text { (ada } \\
\text { gelembung) }\end{array}$ & $\begin{array}{l}\text { Agak } \\
\text { keras }\end{array}$ & Normal & $\begin{array}{l}\text { Kurang } \\
\text { gurih }\end{array}$ & $\begin{array}{c}\text { Kuning } \\
\text { kecoklatan/ } \\
\text { kurang merata } \\
\text { (ada } \\
\text { gelembung) }\end{array}$ & $\begin{array}{l}\text { Agak } \\
\text { keras }\end{array}$ \\
\hline D & Normal & Gurih & Kuning merata & Renyah & Normal & Gurih & $\begin{array}{c}\text { Kuning emas } \\
\text { merata }\end{array}$ & Renyah \\
\hline
\end{tabular}

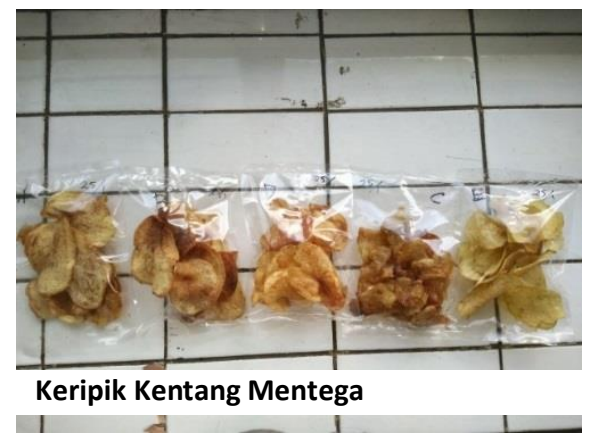

Gambar 6. Penampakan Keripik Kentang

Komponen penyusun aroma terdiri dari senyawa volatil yang mudah menguap pada suhu tinggi, sehingga pada waktu irisan kentang direndam dalam air mendidih, pori-pori jaringan kentang terbuka sehingga pada waktu digoreng sebagian besar senyawa volatil lebih mudah menguap dan bau khas dari kentang menjadi berkurang [16].

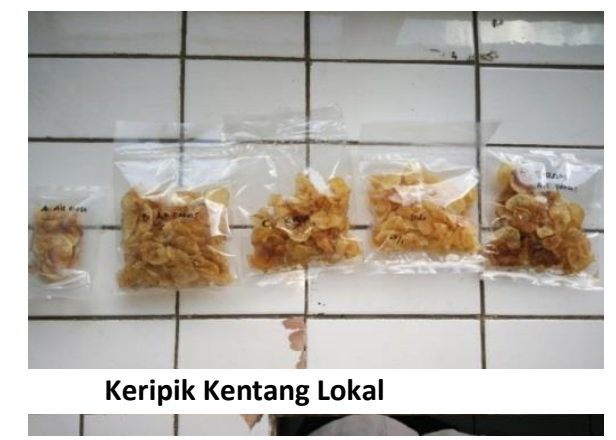

Pada proses pengolahan karena adanya panas maka akan terjadi reaksi maillard akibat interaksi antara karbohidrat (gula reduksi) dan protein (asam amino) menghasilkan senyawa volatil khas produk goreng. Reaksi Maillard melalui degradasi strecker akan menghasilkan senyawa aroma yang enak akibat terbentuknya senyawa furfural dan maltol. Selain 
senyawa furfural dan maltol, degradasi strecker juga menghasilkan komponen herterosiklis hasil kondensasi senyawa intermediet seperti pyrazines, pyrrolines, oxazoles, oxazoline, dan thiazole [19].

Rasa merupakan sensasi yang diproduksi oleh material yang dimasukkan ke dalam mulut, dirasakan prinsipnya oleh indera perasa dan penciuman serta oleh rasa sakit dan suhu dalam mulut [15]. Keripik kentang dalam penelitian ini yang mempunyai rasa gurih (khas keripik kentang) dihasilkan dari perlakuan $D$ (perendaman dalam larutan soda kue 1\%). Sedangkan keripik kentang yang dihasilkan dari perlakuan perendaman dengan air mendidih mempunyai rasa yang tawar/tidak gurih. Hal ini diduga berhubungan dengan komponen yang larut dalam air panas termasuk kandungan gula yang ada dalam jaringan kentang yang ikut keluar dari jaringan sehingga keripik kentang menjadi tawar. Karakteristik rasa pada umbi kentang dipengaruhi oleh komposisi kandungan pati, gula dan solanin. Kandungan gula yang lebih tinggi pada umbi kentang muda (immature) menyebabkan rasa manis, sedangkan kandungan solanin tinggi pada ubi kentang menyebabkan rasa pahit (bitter) pada rasa keripik kentang [15].

Warna bahan makanan merupakan salah satu kriteria mutu yang akan menentukan selera konsumen terhadap produk makanan tersebut sebelum dinilai rasa dan nilai gizinya. SNI 01-4031-1996 tentang syarat mutu keripik kentang mensyaratkan warna keripik kentang adalah kuning sampai coklat muda merata. Hasil uji organoleptik menunjukkan bahwa warna keripik kentang yang memenuhi syarat dihasilkan dari perlakuan $D$ untuk jenis kentang mentega dan kentang lokal (Tabel 2). Warna berhubungan dengan kandungan gula reduksi dari bahan baku, dimana jenis kentang mentega dengan kandungan gula reduksi yang lebih rendah dari jenis kentang lokal cenderung menghasilkan warna keripik yang lebih baik. Sedangkan keripik yang dihasilkan dari perlakuan perendaman dengan air mendidih diduga kandungan gula reduksinya sudah larut dalam air mendidih sehingga pada waktu digoreng menghasilkan warna yang kuning merata. Selain itu perendaman dengan air panas menginaktifkan dan merusak enzim sehingga reaksi pencoklatan dapat dicegah dan warna keripik menjadi cerah. Kandungan gula reduksi yang tinggi menyebabkan terjadinya proses pencoklatan (browning) juga dapat karena adanya reaksi antar komponen bahan pangan selama pengolahan (pencoklatan non enzimatis). Selama penggorengan, adanya suhu tinggi memacu terjadinya reaksi maillard yaitu reaksi antara gula reduksi dan protein pada suhu tinggi yang menyebabkan terjadinya warna coklat pada produk goreng.

Tekstur merupakan salah satu atribut mutu makanan yang penting, kadangkadang lebih penting daripada bau, rasa dan warna. Tekstur merupakan sensasi tekanan yang dapat dinilai dengan mulut (pada waktu digigit, dikunyah, dan ditelan) ataupun perabaan dengan jari [16]. Tekstur keripik kentang yang dihasilkan dalam penelitian ini cenderung dipengaruhi oleh jenis kentang, dimana jenis kentang 
mentega menghasilkan tekstur keripik yang rata-rata lebih renyah dari keripik yang dihasilkan oleh kentang lokal. Sedangkan perendaman dalam larutan soda kue (perlakuan D) dan perendaman dengan air mendidih menghasilkan tekstur keripik yang renyah/lebih renyah dibandingkan perlakuan perendaman lain. Perendaman dalam larutan soda kue atau natrium akan menghasilkan gas $\mathrm{CO}_{2}$, dimana gas $\mathrm{CO}_{2}$ ini dapat membentuk suatu pori-pori dalam keripik kentang yang dihasilkan. Semakin banyak pori-pori yang terbentuk, tekstur keripik yang dihasilkan akan semakin renyah [13]. Perendaman dalam larutan kapur sirih menghasilkan tekstur keripik kentang yang agak keras. Hal ini disebabkan perlakuan perendaman dalam air kapur akan mengakibatkan terbentuknya ikatan antara kalsium dengan pektin dalam jaringan kentang, sehingga tekstur yang terbentuk mejadi keras. Tekstur yang keras dapat menghambat proses penguapan air saat penggorengan sehingga air yang menguap sedikit dan mempercepat pembentukan kerak, akibatnya jumlah kadar minyak bahan juga semakin menurun.

Sebagai parameter utama penentu kualitas keripik maka selain diuji secara organoleptik dilakukan juga pengujian tekstur (kerenyahan) menggunakan alat yang dirancang khusus, dengan cara mengukur intensitas suara (bunyi) yang dihasilkan dari tingkat kekuatan sinyal listrik. Menggunakan software khusus, intensitas suara pada frekuensi tertentu akan terukur dengan skala logarimik desibel. Beberapa hasil pengujian kerenyahan keripik kentang dapat dilihat pada Gambar 7, 8 dan 9.

Gambar 7 menunjukkan hasil uji kerenyahan dari dua jenis kentang pada penyimpanan hari ke-7, dimana pada Gambar ini kelihatan bahwa keripik dari kentang mentega cenderung lebih renyah dari keripik kentang lokal, dan untuk perlakuan A (perendaman dengan air dingin) keripik kentang lokal, tidak ada bunyi/suara yang terukur atau keripik dari perlakuan tersebut tidak renyah.

Gambar 8 menunjukkan bahwa intensitas suara atau kerenyahan keripik kentang mentega pada penyimpanan hari ke-7 yang terukur pada frekuensi tertentu. Dari Gambar tersebut dapat dilihat bahwa kerenyahan keripik kentang yang paling tinggi adalah yang dihasilkan dari perlakuan perendaman dalam larutan soda kue 1\% (perlakuan $\mathrm{D}$ ), diikuti berturut-turut oleh perlakuan $B, C$, dan $A$.

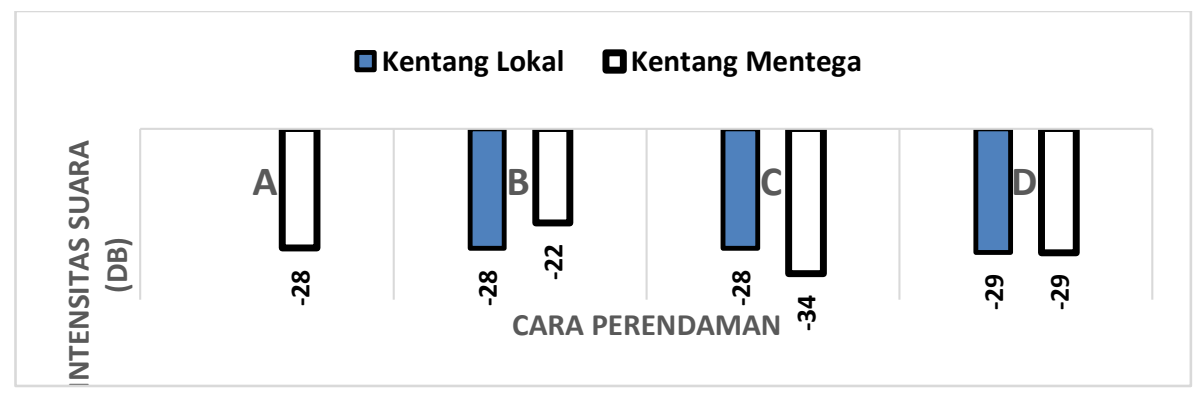

Ket. : $A=$ Rendam air dingin, $B=$ Rendam air $80^{\circ} \mathrm{C} 5$ menit + siram air $100^{\circ} \mathrm{C}$,

Gambar 7. Hasil Uji Kerenyahan Keripik Kentang dari Dua Jenis yang Diukur Berdasarkan Intensitas Suara (dB). 


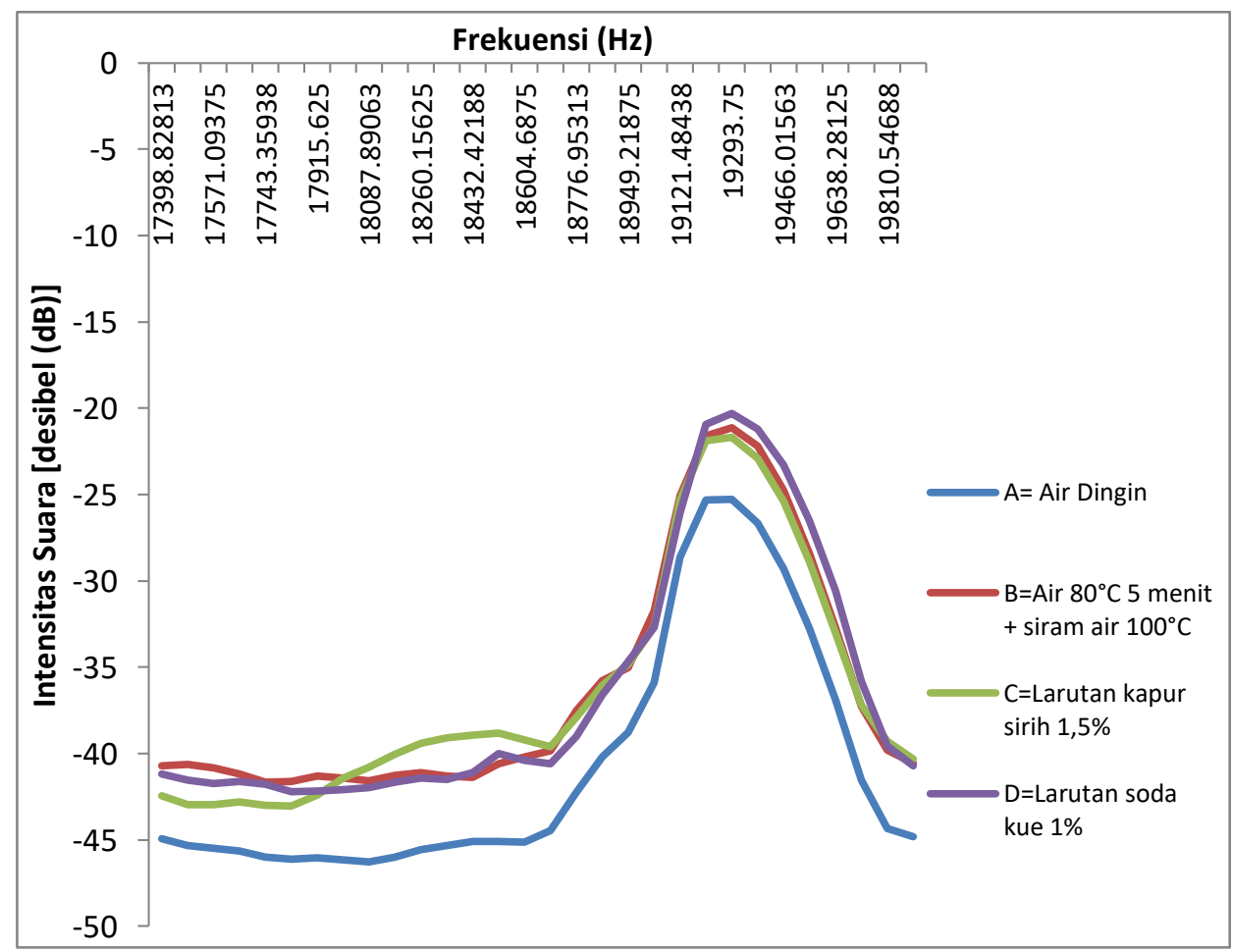

Gambar 8. Hasil Uji Kerenyahan Keripik Kentang Mentega Berdasarkan Intensitas Suara (dB) yang Terukur pada Frekuensi (Hz) Tertentu.

Gambar 9 menunjukkan tingkat intensitas suara dari keripik kentang kerenyahan keripik kentang mentega pada mentega sampai penyimpanan hari ke-7 penyimpanan hari ke-0 dan hari ke-7. masih terukur, atau keripik kentang masih Dimana pada Gambar ini terlihat bahwa renyah.

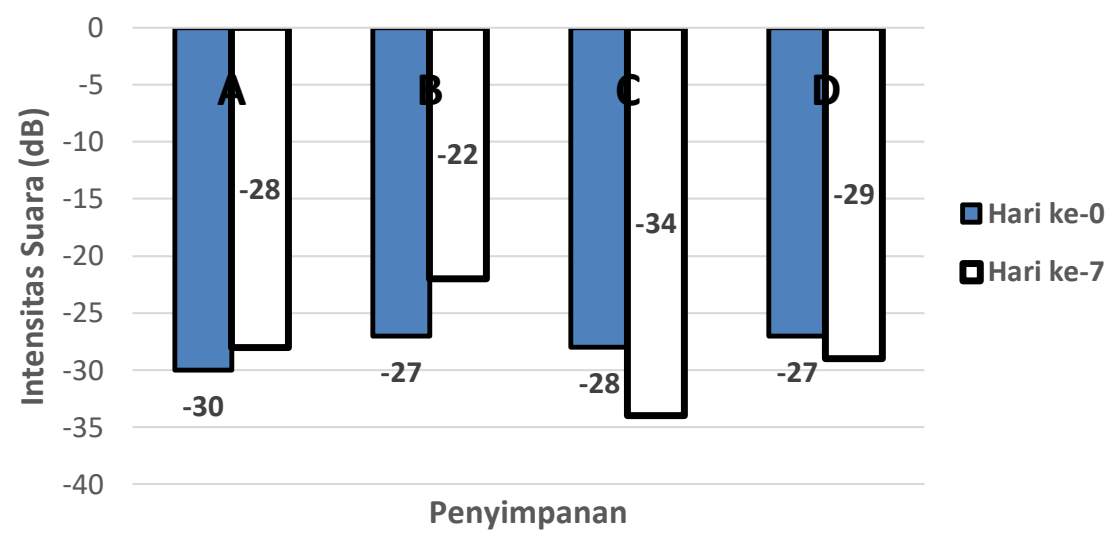

Gambar 9. Hasil Uji Kerenyahan Keripik Kentang Mentega Berdasarkan Intensitas Suara (dB) yang Terukur pada Penyimpanan Hari ke-0 dan Hari ke-7. 


\section{KESIMPULAN}

Mutu keripik kentang dipengaruhi oleh jenis kentang dan cara perendaman. Berdasarkan nilai organoleptik dan pengujian kerenyahan, jenis kentang yang lebih sesuai dijadikan keripik adalah jenis kentang mentega, dimana sampai penyimpanan hari ke-7 masih menghasilkan tekstur yang renyah. Sedangkan untuk jenis kentang lokal yang memenuhi syarat mutu keadaan keripik berdasarkan SNI 01-4031-1996 adalah keripik kentang yang dihasilkan dengan perendaman pada larutan soda kue 1\% selama 30 menit (perlakuan D).

Berdasarkan mutu kimia (kadar air 2,81\%, kadar abu 1,75\% dan kadar lemak $42,28 \%$, keripik kentang yang, memenuhi syarat mutu adalah keripik kentang yang dibuat dengan cara perendaman pada suhu $80^{\circ} \mathrm{C}$ selama 5 menit dilanjutkan dengan disiram dengan air mendidih $100{ }^{\circ} \mathrm{C}$ (perlakuan B).

\section{DAFTAR PUSTAKA}

1. Taulu, L., N. Sutrisno, S. R. Murdiyati. Prospek Pengembangan Kentang di Lahan Kering Dataran Tinggi Sulut. Pusat Penelitian dan Pengembangan Hortikultura. 2013.

2. Adiyoga, W., Asgar, A. dan Suherman, R. Perilaku konsumen dalam membeli produk keripik kentang. Jurnal Hortikultura 9(3): 266-274. 1999.

3. Yunin, Q. A., P. Deoranto dan M. Effendi. Analisis Faktor yang Mempengaruhi Kualitas Keripik Kentang Gizi Food Menggunakan Metode Quality Function Deployment (QFD) (Studi Kasus di UKM Agronas Kota Batu). 2015.

4. Wibowo, C., Dwiyanti, H. dan Haryanti, P. Peningkatan kualitas keripik kentang varietas Granola dengan metode pengolahan sederhana. Jurnal Akta Agrosia 9(2): 102-109. 2006.
5. Astawan, M. Kentang : Sumber Vitamin C dan Pencegah Hipertensi. 2010.

6. Prahardini, P.E.R. dan G. Pratomo. Uji Adaptasi Varietas dan Klon Kentang Olahan Pada Musim Kemarau di Dataran Tinggi Beriklim Kering. Balai Pengkajian Teknologi Pertanian Jawa Timur. 2011.

7. Haryanti, P., B. Sustriawan, dan Sujiman. Perendaman dalam Kalsium Klorida dan Penggunaan Edible Coating untuk Meningkatkan Kualitas French Fries dari Kentang Varietas Tenggo dan Crespo. Jurnal Agritech; 33(1): 38-45. 2013.

8. Ketaren, S. Pengantar Teknologi Minyak dan Lemak Pangan. UI Press, Jakarta. 1986.

9. Ratnawulan, D. Pengaruh Jenis dan Konsentrasi Larutan Kalsium serta Metode Pengeringan terhadap Mutu Keripik Kentang. Skripsi. Institut Pertanian Bogor. Bogor. 1996.

10. Siregar, N. E., Setyohadi, dan M. Nurminah. 2015. Pengaruh Konsentrasi Kapur Sirih (Kalsium Hidroksida) dan Lama Perendaman terhadap Mutu Keripik Biji Durian. J.Rekayasa Pangan dan Pert., Vol.3 No.2 Th. 2015. P. 193-197.

11. Wahyuni, R. Pengaruh Persentase dan Lama Perendaman dalam Kapur Sirih $\left(\mathrm{CaOH}_{2}\right)$ terhadap Kualitas Keripik Talas Ketan (Colocasia esculanta) (Jurnal). Pasuruan: Universitas Yudharta. 2012.

12. Hidayat, N. Manisan Buah, https://ptp2007.wordpress.com/about/. 2007.

13. Luki, C. dan F. C. Nisa. The effect of soaking in calcium hidroxide $\left[\mathrm{Ca}(\mathrm{OH})_{2}\right]$ and natrium bicarbonate (nahco3) on the characteristics of cocoyam chips (Xanthosoma Sagittifolium). 2012.

14. Asgar, A., S. T. Rahayu, M. Kusmana, dan E. Sofiari. Uji Kualitas Umbi Beberapa Klon Kentang untuk Keripik. J. Hort. 21(1):51-59, 2011.

15. Helmi Kurniawan 1) dan Tarkus Suganda. uji kualitas ubi beberapa klon kentang hasil persilangan untuk bahan baku keripik. jurnal agro vol. 1, no. 1, desember 2014. p. 33-43.

16. Sari, T. 2010. Pengaruh Metode Blanching dan Perendaman dalam Kalsium Klorida $\left(\mathrm{CaCl}_{2}\right)$ untuk Meningkatkan Kualitas French Fries dari Kentang Varietas Tenggo dan Crespo (Skripsi). Fakultas Pertanian Universitas Jenderal Soedirman. Purwokerto. 
17. Asandhi, A. dan Kusdibyo. 2004. Waktu Panen Dan Penyimpanan Pasca Panen Untuk Mempertahankan Mutu Umbi Kentang Olahan. Jurnal IImu Pertanian $11(1): 51-62$.
18. Winarno, F.G. dan M. Aman. 1981. Fisiologi Lepas Panen. PT. Sastra Hudaya, Jakarta.

19. Winarno, F.G. Kimia Pangan dan Gizi. PT Gramedia. Pustaka Utama, Jakarta. 2008. 